\title{
A quantitative model for the evaluation of dose rates effects following exposure to low-dose gamma-radiation
}

\author{
H. OGATA ${ }^{1}$, C. FURUKAWA ${ }^{2}$, Y. KAWAKAMI ${ }^{2}$, J. MAGAE ${ }^{2}$
}

(Manuscript received 26 August 2004, accepted 5 February 2005)

ABSTRACT Simultaneous consideration of the irradiation time and the cumulative dose is necessary for evaluating the risk of long-term exposure to radiation at low dose. This study intends to examine several numerical relationships between doses and dose rates in biological responses to gamma radiation. Data on inhibition of $\left[{ }^{3} \mathrm{H}\right]$ thymidine uptake and micronucleus formation in human osteosarcoma cells were analyzed using the median effective dose (MED) as a measure of the risk. MEDs were calculated using parameters estimated by fitting general logistic curves to the dose-response relationships for each group defined by irradiation time. Both biological responses, the inhibition of $\left[{ }^{3} \mathrm{H}\right]$ thymidine uptake and micronucleus formation, decreased sharply when the dose rates were less than $0.01 \mathrm{~Gy} / \mathrm{h}$. Exponential functions were fitted to the log relationships between MEDs and dose rates. This modified exponential model described well the quantitative effect of dose rates on MEDs, and suggested that risk is extremely low at very low dose rates.

Key words: Radiation risk, Dose rate effect, Quantitative model, Risk evaluation, Biological response

RÉSUMÉ Modèle quantitatif pour l'évaluation des effets des débits de dose sur les réponses biologiques à faible dose de radiation gamma.

Pour évaluer le risque d'exposition à long terme aux radiations ionisantes, il est nécessaire de prendre en considération simultanément le temps d'exposition et la dose cumulée. Cette étude propose d'examiner les rapports numériques entre doses et débits de dose dans les réponses biologiques à l'irradiation gamma. Les données sur l'inhibition de l'incorporation de thymidine tritiée, $\left[{ }^{3} \mathbf{H}\right]$ thymidine, et la formation de micro-noyaux dans des cellules d'ostéosarcome d'origine humaine ont été analysées en utilisant la dose médiane efficace (DME) pour mesurer le risque. Les DMEs ont été calculées à l'aide des paramètres estimés à partir des courbes logistiques générales des relations dose-réponse pour chaque groupe expérimental, définies par le temps d'irradiation. Les deux réponses biologiques utilisées, l'inhibition de l'incorporation de thymidine tritiée et la formation de micro-noyaux diminuent fortement pour des débits de dose inférieurs à $0,01 \mathrm{~Gy} / \mathrm{h}$. Des fonctions exponentielles ont été appliquées aux rapports logarithmiques entre DMEs et débits de dose. Ce modèle exponentiel modifié (modèle MOE) décrit bien l'effet quantitatif des débits de dose sur les DMEs et suggère que le risque devient extrêmement faible à très faible débit de dose.

National Institute of Public Health, 2-3-6, Minami, Wako 351-0197 Japan.

2 Institute of Research and Innovation, 1201 Takada, Kashiwa 277-0861, Japan. 


\section{Introduction}

A number of studies have demonstrated that, in general, the biological response to radiation exposure decreases at low dose rate compared with the response at high dose rate. These dose rate effects have been shown at molecular, cellular, tissue and whole-animal levels (Kallmann, 1962; Russell and Kelly, 1982; Morin et al., 1990; Geard and Chen, 1990; Nagasawa et al., 1992; McMillan et al., 1992; Morlier et al., 1992; Académie des Sciences, 1995; Monchaux et al., 1999; Boreham et al., 2000). Other studies have reported that biological response per unit dose increases as dose rate is reduced over a certain, limited dose-rate range. This effect, known as the inverse dose rate effect, has been found for mutation (Crompton et al., 1990; Vilenchik and Knudson, 2000), micronucleus formation (Hill et al., 1984; Widel and Przybyszewski, 1998), and transformation (Miller et al., 1993). The effects of dose rate seem to differ according to the quality of the radiation, the range of doses and dose rates, the biological response being measured, etc. These many observations suggest that biological responses to ionizing radiation are highly complex processes that depend on both dose and dose rate.

To quantitatively evaluate radiation risk, it is necessary to consider the numerical relationships between biological response, cumulative dose and time, because a time factor is implicated in the repair of primary lesions caused by radiation. Mathematical models for cancer risk based on biological considerations such as the multi-stage model (Armitage and Doll, 1954) and the two-event model (Moolgavkar and Venzon, 1979) can describe data on tumour incidences in animals and man. However, the biological mechanisms involved in the production effects at low dose rate have not yet been completely elucidated. Moreover, existing epidemiological data, which could serve as evidence for quantitative estimation the low dose rate effect, is insufficient and lacking in statistical power. Therefore, given the present state of our knowledge, we may have no other choice but to extrapolate from observable data using a quantitative model that include dose and dose rate as parameters.

Our previous paper presented a quantitative analysis for the prediction of irradiation time-dependent biological responses to low dose rate radiation using observed data on growth arrest and micronucleus formation induced by ionizing radiation in human tumor cells to describe the relationships among doses, dose rates, exposure times and biological responses (Magae et al., 2003). The purpose of this paper is to examine numerical relationships between biological responses and dose rates, and to provide a more general form of the model for quantitatively evaluating the effects of dose rates. Through testing some mathematical functions of dose rate versus observed biological response, we developed a modified exponential model (MOE model) to describe the phenomena at low dose rates. 


\section{Experimental methods}

All the experiments have been carried out as described previously (Magae et al., 2003). Cell populations derived from a human osteosarcoma, cell line U2OS, were irradiated in an irradiation room with radiation from a $1850 \mathrm{TBq}{ }^{60} \mathrm{Co}$ source. During irradiation, the cells were cultured at $37{ }^{\circ} \mathrm{C}$ in a $10 \% \mathrm{CO}_{2}$ atmosphere in D-MEM medium supplemented with 5\% fetal bovine serum, $0.05 \mathrm{mM}$ kanamycin and $8 \mu \mathrm{g} / \mathrm{ml}$ tylosin in an incubator placed in the irradiation room. The cells were maintained in exponential growth conditions by passaging into fresh medium twice per week. Dose rate was measured with a photoluminescent dosimeter (PLD). After irradiation, 5000 cells were cultured for $48 \mathrm{~h}$ in a microplate well, and $18.5 \mathrm{kBq}$ of $\left[{ }^{3} \mathrm{H}\right]$-thymidine was pulsed for $4 \mathrm{~h}$ before harvesting. Incorporated radioactivity was measured by liquid scintillation counting. For micronucleus formation measurements, 200,000 irradiated cells were plated on a coverslip and cultured in the presence of $10-\mu \mathrm{M}$ cytochalasin B for $24 \mathrm{~h}$ to block cytokinesis. Cells were washed with PBS, fixed with $4 \%$ aqueous formaldehyde solution for $15 \mathrm{~min}$, and incubated with 4,6-diamidino-2-phenylindole (DAPI, $100 \mathrm{ng} / \mathrm{ml}$ ) and propidium iodide $(1 \mu \mathrm{g} / \mathrm{ml})$ to stain the nucleus and cytoplasm. The number of cells with micronuclei among 200 binucleate cells was counted by fluorescence microscopy.

\section{Mathematical analysis}

Biological responses are often described by a logistic regression model when the response variable is binary. The model used for dose-response analyses in this paper is a general logistic function in which the proportion $(p)$ of cells there are $\left[{ }^{3} \mathrm{H}\right]$-thymidine uptake inhibition or bearing micronucleus binuclear cells at cumulative dose $x$ is expressed as

$$
p=a /[1+\exp (c x+b)]
$$

where $a$ is the maximum proportion of the response $(0<a \leq 1), b$ and $c$ are parameters. This equation can be rewritten using the logit of $p$ as follows:

$$
\ln [p /(a-p)]=-(c x+b)
$$

There are several reasons for using this model. It is a flexible and easily used function from a mathematical point of view. In this model, the dose-response curve is sigmoid, or S-shaped, and $p$ does not exceed $a$. The proportion of subjects who 
respond at each dose level represents the cumulative distribution function of the probability of the response to radiation. We used the median effective dose (MED) as a measure to characterize this distribution, because the point estimator of the MED is not subject to measurement errors and is more reliable than the response at either tail of the distribution (Ashford, 1985; Morgan, 1992; Armitage and Colton, 1998). The MED is equivalent to $\mathrm{ED}_{50 a}$ (the effective dose 50a), the dose that causes a measurable response in $0.5 a$ probability (i.e. $50 a \%$ ) of the cells. As the probability of biological response often reaches a maximum level $(=a)$ at less than one, it is more appropriate to use the MED rather than $\mathrm{ED}_{50}$ (the dose level at which $50 \%$ of the group have responded) in calculations. If $p=0.5 a$ then $\ln [p /(a-p)]=-(c x+b)=0$, that is, the MED is given by

$$
M E D=-b / c
$$

If the dose-response curve depends on dose rate, the MED also depends on dose rate for a constant irradiation time, or depends on irradiation time at a constant dose rate. To evaluate the effect of dose rate on MEDs which were estimated by equation (3), we consider the following functions that can describe the relationship between the MED and the dose rate.

First, if the MED is expressed by any function of the irradiation time $t$ at a constant dose rate $r$, the MED can be expressed as a function of $r$ at a constant $t$. We will demonstrate later that a linear function fits well to the relationship between the MED and the irradiation time $t$. If $M E D=d_{0}+d_{1} t$, where $d_{0}$ and $d_{1}$ are parameters, because $t=(M E D) / r$ and $M E D=d_{0}+d_{1}(M E D) / r$, then the MED is given by

$$
M E D=\frac{d_{0}}{1-d_{1} / r},
$$

where $d_{0}>0$ and $r>d_{1}$. We calculated $d_{0}$ and $d_{1}$ by the least squares method.

Second, assuming that response $p$ depends on the cumulative dose $x$, the dose rate $r$ and the irradiation time $t$, we fit the following multiple logistic function to the data:

$$
p=a /\left(1+\exp \left(b_{0}+b_{1} t+b_{2} r+b_{3} x\right)\right)
$$

where $b_{0}, b_{1}, b_{2}$ and $b_{3}$ are parameters. Here, since the variables are related by $x=t r$, the term $b_{3} x$ denotes the interactive effect of the irradiation time $t$ and the dose rate $r$. Equation (5) can be rearranged to the following:

$$
\ln [p /(a-p)]=-\left(b_{0}+b_{1} t+b_{2} r+b_{3} x\right)
$$


If $p=0.5 a$ then $-\left(b_{0}+b_{1} t+b_{2} r+b_{3} x\right)=0$, that is, the MED is given by

$$
M E D=-\frac{b_{0}+b_{2} r}{b_{1} / r+b_{3}},
$$

where the range of $r$ depends on the values of the parameters.

Third, our previous analyses showed that $\log \left[\mathrm{ED}_{50}\right]$ for inhibition of $\left[{ }^{3} \mathrm{H}\right]-$ thymidine uptake and $\log \left[\mathrm{ED}_{30}\right]$ for micronucleus formation are well described by an exponential function of the logarithm of the dose rate (Magae et al., 2003). Here, instead of $\mathrm{ED}_{50}$ and $\mathrm{ED}_{30}$, we used the $\mathrm{MED}=\mathrm{ED}_{50 a}$. This model $(\mathrm{MOE}$ model) which provides a more general description of the response is expressed as follows:

$$
\log M E D=\mu+\exp (\alpha+\beta \log r)
$$

where $\alpha, \beta$ and $\mu$ are parameters.

Parameters were calculated by the iterative least squares method (Neter et al., 1989), using SPSS (Norusis, 1999) and STATISTICA (StatSoft Inc., 1999) software tool kits.

\section{Results}

Table I shows MEDs estimated by fitting a general logistic function for each group defined by irradiation time. Also shown are dose rates which were calculated from equation: $(M E D) /($ irradiation time). It is evident that the MED increases with longer irradiation time for both the inhibition of $\left[{ }^{3} \mathrm{H}\right]$ thymidine uptake and micronucleus formation. In Figure 1, we plot observed values of $\ln [p /(a-p)]$ and draw estimated lines of general logistic function. The intersection of the resulting regression line with the line $\ln [p /(a-p)]=0$ denotes the MED. The relationship between the MED and irradiation time is shown in Figure 2. The linear regression lines have a good fit to the data for both responses. Estimates of the parameters were as follows: $d_{0}=0.021, d_{1}=2.587$ (correlation coefficient $=0.980$ ) for inhibition of $\left[{ }^{3} \mathrm{H}\right]$ thymidine uptake, and $d_{0}=0.017, d_{1}=1.508$ (correlation coefficient $=0.883$ ) for micronucleus formation. Figure 3 shows the relationships between MEDs and dose rates calculated with equations (4) and (7). It is clear that for both responses MEDs increase sharply when the dose rate is less than $0.1 \mathrm{~Gy} / \mathrm{h}$. In equation (4), the MED approaches $d_{0}$ when $r$ approaches infinity, where $r>d_{1}$. An increase in MEDs signifies a decline of the response, or a reduction of the risk. Therefore these results suggest that the risk was reduced at very low dose rates. However, the range over which equations (4) and (7) are effective is mathematically limited to dose rates roughly from 0.05 to $10 \mathrm{~Gy} / \mathrm{h}$, and these 
TABLE I

MEDs estimated by using general logistic functions for inhibition of $\left[{ }^{3} \mathrm{H}\right]$ thymidine uptake and micronucleus formation. U2OS cells were irradiated for the indicated times. Dose rates were calculated by the equation: $(M E D) /($ irradiation time).

DMEs (doses médianes efficaces) estimées par l'application des fonctions logistiques générales aux données de l'incorporation de $\left[{ }^{3} \mathrm{H}\right]$ thymidine et de la formation de micro-noyaux. Les cellules U2OS ont été irradiées pendant les temps indiqués. Les débits de dose ont été calculés par l'équation : $(D M E)$ / (temps de l'irradiation).

\begin{tabular}{|c|c|c|c|c|}
\hline \multirow{2}{*}{ Irradiation time $(\mathrm{h})$} & \multicolumn{2}{|c|}{ Inhibition of $\left[{ }^{3} \mathrm{H}\right]$ thymidine uptake } & \multicolumn{2}{|c|}{ Micronucleus formation } \\
\hline & MED (Gy) & Dose rate $(\mathrm{Gy} / \mathrm{h})$ & MED (Gy) & Dose rate $(\mathrm{Gy} / \mathrm{h})$ \\
\hline 0.017 & 1.840 & 110.413 & 0.650 & 39.009 \\
\hline 0.167 & 1.990 & 11.940 & 0.488 & 2.929 \\
\hline 1.667 & 2.313 & 1.388 & 0.770 & 0.462 \\
\hline 5.000 & 2.706 & 0.541 & 2.094 & 0.419 \\
\hline 19.050 & 3.141 & 0.165 & 1.186 & 0.062 \\
\hline 44.610 & 3.977 & 0.089 & 1.857 & 0.042 \\
\hline 67.620 & 4.207 & 0.062 & 2.732 & 0.040 \\
\hline 87.660 & 5.404 & 0.062 & 3.211 & 0.037 \\
\hline 120.270 & 4.589 & 0.038 & 2.969 & 0.025 \\
\hline 187.770 & 5.911 & 0.031 & 10.406 & 0.055 \\
\hline 306.900 & 11.461 & 0.037 & 5.833 & 0.019 \\
\hline 468.860 & 12.049 & 0.026 & 8.156 & 0.017 \\
\hline 633.800 & 15.521 & 0.024 & 11.834 & 0.019 \\
\hline
\end{tabular}

functions can not be applied to very low dose rates. To estimate the effect of dose rate in a more general form, we used equation (8), the MOE model. This model has no mathematical limitation on the range of dose rate. We obtained parameter estimates of the model: $\alpha=-3.340, \beta=-1.916, \mu=0.316$ for the inhibition of $\left[{ }^{3} \mathrm{H}\right]$ thymidine uptake and $\alpha=-1.662, \beta=-1.013, \mu=-0.264$ for the micronucleus formation. Figure 4 shows the relationships between MEDs and dose rates. Fitted curves for $\mathrm{ED}_{25 a}$ and $\mathrm{ED}_{75 a}$ versus dose rate are also shown, where $25 a$ and $75 a$ denote respectively the lower and upper quartiles of the cumulative response distribution. For the three models (Eqs. (4), (7) and (8)) for $\log M E D$, residual sums of squares which are simple measures of the fitness of the model are as follows: $0.193,0.221$ and 0.129 respectively for the inhibition of $\left[{ }^{3} \mathrm{H}\right]$ thymidine uptake, and 1.699, 2.573 and 0.775 for the micronucleus formation. It was clear that three models produced similar fits and equation (8) fitted best to the data among three models. 
QUANTITATIVE MODEL FOR EVALUATION OF DOSE RATES EFFECTS

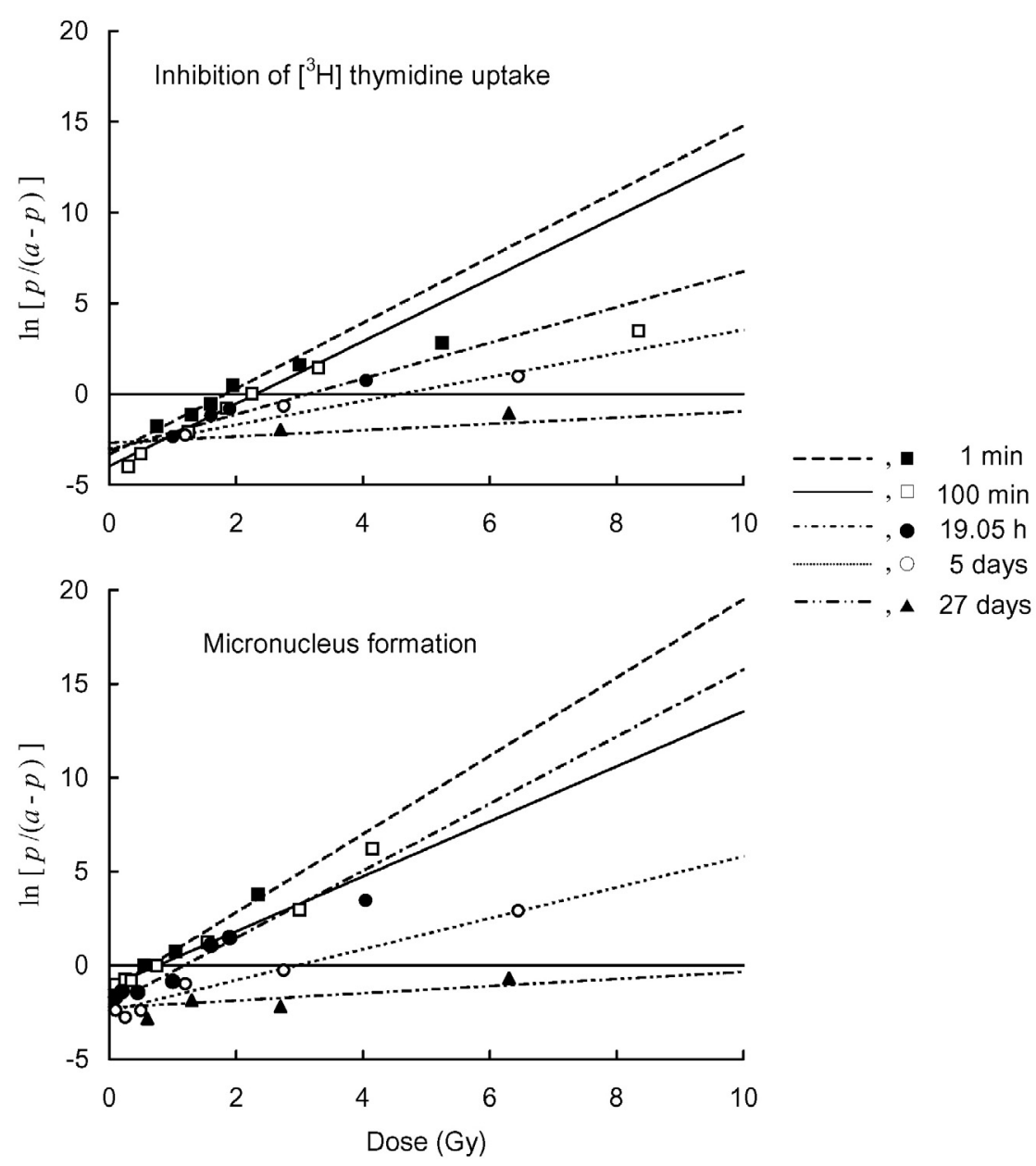

Figure 1 - Logit of the response (i.e. $\ln [p /(a-p)])$, where $p$ is the proportion of cells showing the effect, versus dose at a constant irradiation time for inhibition of $\left[{ }^{3} \mathrm{H}\right]$ thymidine uptake and micronucleus formation. Each line represents fitted general logistic function. The intersection points of the estimated line with the line $\ln [p /(a-p)]=0$ denotes the MED.

Logit de la réponse (soit, $\ln [p /(a-p)]$ ), où p représente la proportion de cellules montrant un effet, en fonction de la dose, respectivement pour l'inhibition de l'incorporation de $\left[{ }^{3} \mathrm{H}\right]$ thymidine et la formation de micro-noyaux. Chaque ligne représente la fonction logistique générale appliquée aux données pour des temps d'irradiation constants. Les points d'intersection de la ligne estimée avec la ligne $\ln [p /(a-p)]=0$, indiquent la DME. 


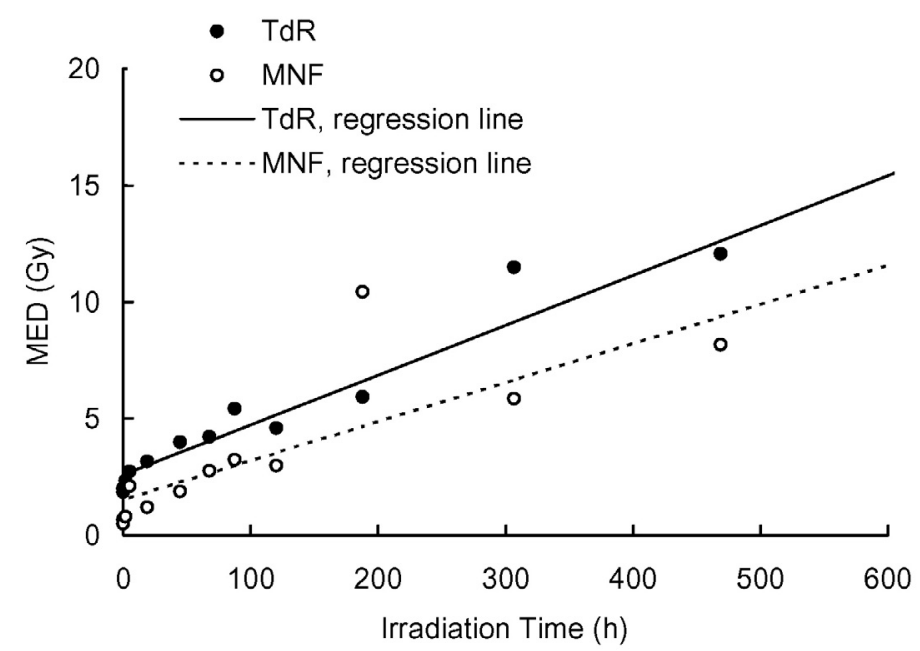

Figure 2 - MED versus irradiation time for inhibition of $\left[^{3} \mathrm{H}\right]$ thymidine uptake (TdR) and micronucleus formation $(M N F)$. Each line represents the linear regression.

DME en fonction du temps d'irradiation pour l'inhibition de l'incorporation de $\left[^{3} H\right]$ thymidine (TdR) et la formation de micro-noyaux (MNF). Chaque ligne représente la régression linéaire.

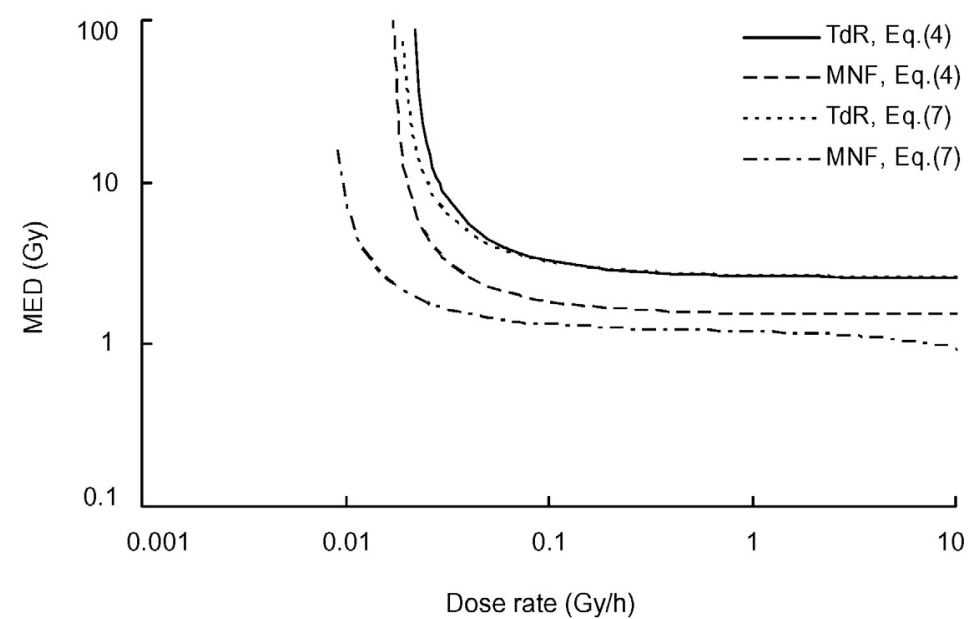

Figure 3 - Numerical relationships between MEDs and dose rates estimated by equations (4) and (7). TdR and MNF represent respectively inhibition of $\left[{ }^{3} \mathrm{H}\right]$ thymidine uptake and micronucleus formation.

Relations numériques entre DMEs et débits de dose estimés pour les équations (4) et (7). TdR et $M N F$ représentent respectivement l'inhibition de l'incorporation de $\left[{ }^{3} \mathrm{H}\right]$ thymidine et la formation de micro-noyaux. 
QUANTITATIVE MODEL FOR EVALUATION OF DOSE RATES EFFECTS
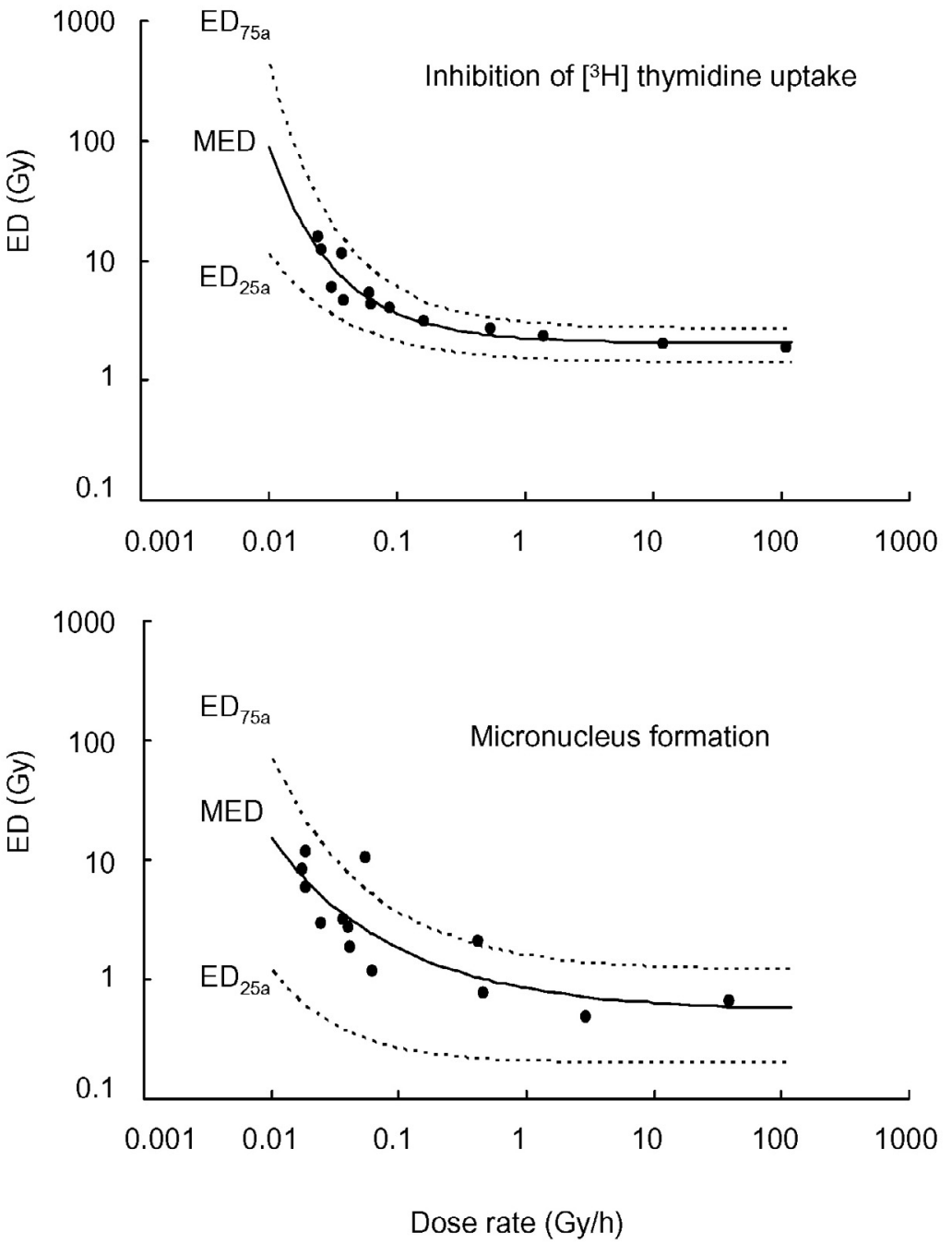

Figure 4-Numerical relationships between $E D s\left(E D_{75 w}, M E D, E D_{25 a}\right)$ and dose rates for inhibition of $\left[{ }^{3} \mathrm{H}\right]$ thymidine uptake and micronucleus formation. Curves were obtained by equation (8) (MOE model). Circles represent MEDs calculated by general logistic function for various irradiation times.

Relations numériques entre les doses efficaces (DEs, $\mathrm{DE}_{75 a}, \mathrm{DME}, \mathrm{DE} \mathrm{Da}_{25}$ ) et débits de dose estimés pour l'inhibition de l'incorporation de [ ${ }^{3} \mathrm{H}$ ] thymidine et la formation de micronoyaux. Les courbes ont été obtenues par l'équation (8) (modèle MOE). Les cercles représentent les MEDs calculées par fonction logistique générale pour différents temps d'irradiation. 


\section{Discussion}

We applied some functional expressions to describe the quantitative relationship between MEDs and dose rates in biological response to gamma radiation in human osteosarcoma cells. The results from these analyses showed that the MED decreases when dose rate increases and eventually approaching a minimum constant level, but it increases sharply at very low dose rates. The relationships of $\mathrm{LD}_{50}$ (the lethal dose 50 , the lethal dose for $50 \%$ of the group) to the dose rate of low-LET (Linear Energy Transfer) radiation exposure for marrow-syndrome lethality in human (Ainsworth et al., 1965), rat (Logie et al., 1960), mouse (Koznova, 1978), and other species have been reported. These studies showed that the curves for $\mathrm{LD}_{50}$ versus dose rate converge at high dose rates to a common $\mathrm{LD}_{50}$ for dog, swine, goat, and human (Scott et al., 1988). Furthermore, the curves for $\mathrm{LD}_{50}$ versus dose rate for many kinds of animal and man have a similar shape to that produced by the MOE model, and this suggests that the model is applicable for a wide range data.

The curves describing the relationship between MED and dose rate sharply change the slopes at approximately $0.1 \mathrm{~Gy} / \mathrm{h}$, as shown in Figure 4 . It could be speculated that at this point cell repair mechanisms rapidly lose their ability to repair induced damage. Based on our data, we conclude that, from the viewpoint of risk evaluation, it is useful to consider three main dose rate ranges. In the middle range (roughly from 0.1 to $1 \mathrm{~Gy} / \mathrm{h}$ ), the response depends on both dose and dose rate. At very low dose rates (less than $0.1 \mathrm{~Gy} / \mathrm{h}$ ) the MED increases sharply, therefore the response depends strongly on dose rate. At higher dose rate (greater than $1 \mathrm{~Gy} / \mathrm{h}$ ), the MED approaches a minimum constant level, the response no longer depends on dose rate, i.e. it depends on only total cumulative dose.

The theory of dual radiation action describes the relationship between chromosome aberration and radiation dose (Kellerer and Rossi, 1972). This model has been used as a general dose-response model, by which risk is calculated using the expression $\beta_{1} D+\beta_{2} D^{2}$ where $D$ is the dose, $\beta_{1}$ and $\beta_{2}$ are parameters, a linearquadratic polynomial. In this model, $\beta_{2} D^{2}$ becomes negligible at low dose levels and the relationship is then linear. It has been demonstrated that the value of the parameter $\beta_{1}$ is greater at high dose rates than at low dose rates for some biological responses including mutation frequency (Russell, 1977; Selby et al., 1991) and formation of micronuclei in early spermatids (Kunugita et al., 2002). A decrease of value of $\beta_{1}$ is generally reflected in an increase of the MED. Therefore, if the parameter $\beta_{1}$ is expressed as a function of dose rate, which is continuous variable, then the MED as a measure of the risk can be described as a continuous function of dose rate. However, there is little basis for the relationship between $\beta_{1}$ and dose rate at low dose rate. From a statistical point of view, the shape of a dose-response curve at very low dose and very high dose, i.e. the tails of the response distribution, 
are subject to significant measurement error (Ashford, 1985; Morgan, 1992). A large uncertainty, or a lack of statistical power, always remains for any measure of biological response at low dose level. This statistical consideration underscores the difficulty in directly evaluating low dose radiation risk. However, the use of the MED as a point estimator circumvents measurement error (Armitage and Colton, 1998) and can reduce uncertainty due to the lack of information.

The survivors of Hiroshima and Nagasaki were exposed to doses ranging from $0.005 \mathrm{~Sv}$ to several Sv. Because exposure time was less than one second (Académie des Sciences, 1995), the dose rate range was between $10^{1}$ and $10^{4} \mathrm{~Sv} / \mathrm{h}$. The lowest experimentally accessible dose rates are on the order of $10^{-3} \mathrm{~Sv} / \mathrm{h}$. However, the dose rates usually considered for environmental, but not medical radioprotection correspond to the order of $10^{-7} \mathrm{~Sv} / \mathrm{h}$ or less, which is less than one 10000 th of the minimum rate for which actual data is obtainable. Therefore a quantitative model is required to allow extrapolation of the risk level in the interval between experimentally obtainable dose rates and actual environmental background radiation levels.

In conclusion, the MOE model describes the quantitative relationship between effect and dose rate for cell proliferation arrest and micronucleus formation induced by ionizing radiation in human tumor cells. The results that there is a dose rate range over which risk depends on both dose and dose rate, but that risk depends primarily on dose rate at dose rate lower than about $0.1 \mathrm{~Sv} / \mathrm{h}$. In this context, micronucleus formation is one end point that does seem to be show an inverse-dose rate effect (at least in lung cells). A claimed advantage of the model developped is that it widely appreciated and can be used to test predictions for other experimental or epidemiological data. In this respect, the model is particularly useful since it is applicable over a wide dose rate range extending from those typical of environmental background to those typical of medical and experimental.

\section{REFERENCES}

Académie des Sciences (1995) Problèmes Liés aux Effets des Faibles Doses des Radiations Ionisantes. Rapport $n^{\circ} 34$. Technique et Documentation, Paris.

Ainsworth E.J., Leong G.F., Kendall K., Alpen E.L. (1965) Comparative lethality responses of neutron and X-irradiated dogs: Influence of dose rate and exposure aspect, Radiat. Res. 26, 32-43.

Armitage P., Colton T. (Eds.) (1998) Encyclopedia of Biostatistics, p. 1727. Wiley, Chichester.

Armitage P., Doll R. (1954) The age distribution of cancer and multi-stage theory of carcinogenesis, Br. J. Cancer 8, 1-12.

Ashford J.R. (1985) Quantal response analysis, in: Encyclopedia of Statistical Sciences, Vol. 7 (Kotz S., Johnson N., Eds), pp. 402-406. Wiley, New York.

Boreham D.R., Dolling J.A., Maves S.R., Siwarungsum N., Mitchel R.E. (2000) Dose rate effects for apoptosis and micronucleus formation in gamma-irradiated human lymphocytes, Radiat. Res. 153, 579-586.

Crompton N.E.A., Barth B., Kiefer J. (1990) Inverse dose rate effect for the induction of 6-thioguanineresistant mutations in Chinese hamster V79-S cells by ${ }^{60} \mathrm{Co} \gamma$-rays, Radiat. Res. 124, 300-308. 
Geard C.R., Chen C.Y. (1990) Micronuclei and clonogenicity following low- and high-dose rate gamma irradiation of normal human fibroblasts, Radiat. Res. 124, S56-S51.

Hill C.K., Han A., Elkind M.M. (1984) Fission spectrum neutrons at low dose rate enhance neoplastic transformation in the linear, low dose region (0-10 cGy), Int. J. Radiat. Biol. 46, 11-15.

Kallmann R.F. (1962) The effect of dose rate on mode of acute radiation death of C57BL and BALB/c mice, Radiat. Res. 16, 796-810.

Kellerer A.M., Rossi H.H. (1972) The theory of dual radiation action, Curr. Topics Radiat. Res. 8, 85158.

Koznova L.B. (1978) Effects of radiation dose rate on median enteric syndromes, Radiobiologiia 18, 63-69.

Kunugita N., Kakihara H., Kawamoto T., Norimura T. (2002) Micronuclei induced by low dose rate irradiation in early spermatids of p53 null and wild mice, J. Radiat. Res. 43, S205-S207.

Logie L.C., Harris M.D., Tatsch, R.E., Van Hooser E.N. (1960) An analysis of the $\mathrm{LD}_{50 / 30}$ as related to radiation sensitivity, Radiat. Res. 12, 349-356.

Magae J., Hoshi Y., Furukawa C., Kawakami Y., Ogata H. (2003) Quantitative analysis of biological responses to ionizing radiation, including dose, irradiation time and dose rate, Radiat. Res. 160, 543-548.

McMillan T.J., Eady J.J., Peacock J.H., Steel G.G. (1992) Cellular recovery in two sub-lines of the L5178 Y murine leukemic lymphoblast cell line differing in their sensitivity to ionizing radiation, Int. J. Radiat. Biol. 61, 49-56.

Miller R.C., Randers-Pehrson G., Hieber L., Marino S.A., Richards M. Hall E.J. (1993) The inverse dose rate effect for oncogenic transformation by charged particles is dependent on linear energy transfer, Radiat. Res. 133, 360-364.

Monchaux G., Morlier J.P., Altmeyer S., Debroche M., Morin M. (1999) Influence of exposure rate on lung cancer induction in rats exposed to radon progeny, Radiat. Res. 152, S137-S140.

Moolgavkar S.H., Venzon D.J. (1979) Two-event models for carcinogenesis: incidence curves for childhood and adult tumours, Math. Biosci. 47, 55-77.

Morgan B.J.T. (1992) Analysis of Quantal Response Data. Chapman \& Hall, London.

Morin M., Masse R., Lafuma J. (1990) Effets cancérogènes de l'irradiation gamma à faible débit de dose, C.R. Ac. Sc. 311, 459-466.

Morlier J.P., Morin M., Chameaud J., Masse R., Bothard S., Lafuma J. (1992) Importance du role du débit de dose sur l'apparition des cancers chez le rat après inhalation de radon, C.R.Ac.Sc. $\mathbf{3 1 5}$ 463-466.

Nagasawa H., Little J.B., Tsang N.M., Saunders E., Tesmer J., Strniste G.F. (1992) Effect of dose rate on the survival of irradiated human skin fibroblasts, Radiat. Res. 132, 375-379.

Neter J., Wasserman W., Kunter M.H. (1989) Applied Linear Regression Models, 2nd edn. Irwin, Homewood.

Norusis M.J. (1999) SPSS Regression Models ${ }^{T M}$, Ver. 10.0. SPSS Inc., Chicago.

Russell W.L. (1977) Mutation frequencies in female mice and the estimation of genetic hazards of radiation in women, Proc. Natl. Acad. Sci. U.S.A. 74, 3523-3527.

Russell W.L., Kelly E.M. (1982) Mutation frequencies in male mice and the estimation of genetic hazards of radiation in men, Proc. Natl. Acad. Sci. U.S.A. 79, 542-544.

Scott B.R., Hahn F.F., McClellan R.O., Seiler F.A. (1988) Risk estimators for radiation-induced bone marrow syndrome lethality in humans, Risk Analysis 8, 393-402.

Selby P.B., Lee S.S., Kelly E.M., Bangham J.W., Raymer G.D., Hunsicker P.R. (1991) Specific-locus experiments show that female mice exposed near the time of birth to low-LET ionizing radiation exhibit both a low mutational response and a dose rate effect, Mutat. Res. 249, 351-367.

StatSoft Inc. (1999) STATISTICA User's Manual. StatSoft Inc. Japan, Tokyo.

Vilenchik M.M., Knudson A.G. Jr. (2000) Inverse radiation dose rate effects on somatic and germ-line mutations and DNA damage rates, Proc. Natl. Acad. Sci. U.S.A. 97, 5381-5386.

Widel M., Przybyszewski W.M. (1998) Inverse dose rate effect for the induction of micronuclei in Lewis lung carcinoma after exposure to cobalt-60 gamma rays, Radiat. Res. 149, 98-102. 